\title{
Penyalahgunaan Fungsi Tanah Kas Desa di Kecamatan Banguntapan Kabupaten Bantul Daerah Istimewa Yogyakarta
}

\author{
Fattahillah Fahmi \\ Magister Kenotariatan Universitas Islam Indonesia \\ Jl. Cik Di Tiro Yogyakarta \\ fattahillahfahmi@gmail.com
}

\begin{abstract}
This study discusses the misuse of land in the District Rural village treasury Banguntapan Bantul Yogyakarta. This type of research used in this research is the empirical jurisdiction. The study concluded that the abuse of cash land Banguntapan village in the district of Bantul Regency involve various stakeholders ranging from the government, the communities, and also the local notary. Cash Land Village is one of the village valuable asset because it serves as the village's largest revenue source then sebaikanya existence should be safeguarded. The village government must act decisively against the survival of the village treasury land and provide sanctions against infringing on the case. So that the wealth of the village could be felt by all people, especially villagers do not violate regulations.
\end{abstract}

Keywords: Soil village treasury, Notary, Bantul.

\begin{abstract}
Abstrak
Penelitian ini membahas tentang penyalahgunaan tanah kas desa Desa di Kecamatan Banguntapan Kabupaten Bantul Daerah Istimewa Yogyakarta. Jenis penelitian yang digunakan dalam penelitian ini adalah yuridis empiris. Hasil penelitian menyimpulkan bahwa proses penyalahgunaan tanah kas desa di Kecamatan Banguntapan Kabupaten Bantul melibatkan berbagai pihak mulai dari pemerintah desa, masyarakat, dan juga notaris setempat. Tanah Kas Desa merupakan salah satu aset desa yang berharga karena berfungsi sebagai sumber pemasukan terbesar desa maka sebaikanya keberadaanya harus dijaga. Pemerintah desa harus bertindak tegas terhadap kelangsungan tanah kas desa dan memberikan sanksi terhadap pelanggaraan yang terjadi. Sehingga kekayaan desa tersebut bisa dirasakan manfaatnya oleh semua orang terutama warga desa dengan tidak melanggar peraturan yang berlaku.
\end{abstract}

Kata-kata Kunci: Tanah kas desa, Notaris, Bantul. 


\section{Pendahuluan}

Tanah Kas Desa merupakan Tanah Negara yang diserahkan kepada Desa untuk dimanfaatkan bagi kepentingan desa. Dalam Instruksi Menteri Dalam Negeri Nomor 22 Tahun 1996 Tentang Pengadaan, Pengelolaan dan Pengembangan Tanah Kas Desa ditekankan kembali bahwa Tanah Kas Desa merupakan salah satu sumber pendapatan yang potensial dan dapat dikembangkan. Berhubungan dengan itu, maka pengadaan dan pengembangan Tanah Kas Desa menjadi sangat penting untuk diatur. Mengingat peran Tanah Kas Desa yang strategis dalam pembangunan desa, maka di dalam Instruksi Menteri Dalam Menteri tersebut Gubernur dan Bupati/Walikota se-Indonesia di instruksikan untuk melaksanakan, membina, dan menyediakan biaya untuk pengadaan, pengelolaan, dan pengembangan Tanah Kas Desa serta melaporkan hasil kerja tersebut kepada Menteri.

Upaya peningkatan kemampuan pemerintah desa dalam penyelenggaraan pemerintahan, pelaksanaan pembangunan dan khususnya pelayanan kepada masyarakat memerlukan sumber dana yang memadai yaitu salah satunya dengan pemanfaatan Tanah Kas Desa.

Kecamatan Banguntapan adalah salah satu kecamatan yang paling berkembang di Kabupaten Bantul, dan dengan jumlah penduduk terbanyak di Kabupaten Bantul dan nomer 2 Di DIY setelah Kecamatan Depok di Kabupaten Sleman. ${ }^{1}$ Karena secara geografis letak kecamatan ini termasuk strategis karena berbatasan dengan: Utara: Kecamatan Depok (Sleman), Timur: Kecamatan Piyungan, Selatan: Kecamatan Pleret; Barat: Kecamatan Kotagede, Kecamatan Umbulharjo (Kota Yogyakarta).

${ }^{1}$ Berdasarkan data di Badan Pusat Statistik Daerah Istimewa Yogyakarta, hasil sensus tahun 2010. 
Tabel 1. Jumlah Penduduk Kabupaten Bantul menurut Kecamatan

\begin{tabular}{|l|l|c|c|c|c|c|c|}
\hline \multirow{2}{*}{ No } & Kecamatan & \multicolumn{7}{|c|}{ Penduduk } \\
\cline { 2 - 8 } & & $\mathbf{1 9 6 1}$ & $\mathbf{1 9 7 1}$ & $\mathbf{1 9 8 0}$ & $\mathbf{1 9 9 0}$ & $\mathbf{2 0 0 0}$ & $\mathbf{2 0 1 0}$ \\
\hline $\mathbf{1}$ & Srandakan & 22644 & 25.190 & 26.641 & 26.445 & 27.180 & 28.572 \\
\hline $\mathbf{2}$ & Sanden & 25.064 & 27.648 & 28.526 & 27.434 & 28.543 & 29.667 \\
\hline $\mathbf{3}$ & Kretek & 25.193 & 28.175 & 27.250 & 25.878 & 26.871 & 29.163 \\
\hline $\mathbf{4}$ & Pundong & 26.211 & 29.002 & 29.643 & 29.657 & 30.042 & 31.667 \\
\hline $\mathbf{5}$ & Bambanglipuro & 30.112 & 34.303 & 35.065 & 34.699 & 35.165 & 37.330 \\
\hline $\mathbf{6}$ & Pandak & 32.122 & 36.787 & 40.530 & 42.632 & 44.604 & 47.694 \\
\hline $\mathbf{7}$ & Bantul & 33.946 & 40.585 & 45.587 & 49.238 & 52.597 & 59.227 \\
\hline $\mathbf{8}$ & Jetis & 32.664 & 37.550 & 40.932 & 43.229 & 46.474 & 51.925 \\
\hline $\mathbf{9}$ & Imogiri & 38.548 & 42.067 & 46.084 & 49.706 & 51.710 & 56.219 \\
\hline $\mathbf{1 0}$ & Dlingo & 24.598 & 28.477 & 30.022 & 30.245 & 33.148 & 35.504 \\
\hline $\mathbf{1 1}$ & Pleret & 22.598 & 25.631 & 30.022 & 30.245 & 33.148 & 43.269 \\
\hline $\mathbf{1 2}$ & Piyungan & 25.708 & 28.939 & 33.168 & 35.142 & 38.568 & 48.660 \\
\hline $\mathbf{1 3}$ & Banguntapan & 37.733 & 43.958 & 56.335 & 71.727 & 88.437 & 120.015 \\
\hline $\mathbf{1 4}$ & Sewon & 41.792 & 48.990 & 57.820 & 69.656 & 86.414 & 104.368 \\
\hline $\mathbf{1 5}$ & Kasihan & 35.684 & 42.481 & 51.913 & 68.683 & 86.846 & 110.871 \\
\hline $\mathbf{1 6}$ & Pajangan & 18.054 & 20.447 & 23.128 & 25.261 & 27.892 & 32.852 \\
\hline $\mathbf{1 7}$ & Sedayu & 26.125 & 28.397 & 31.751 & 34.476 & 39.575 & 44.450 \\
\hline & Jumlah & $\mathbf{4 9 9 . 1 6 3}$ & $\mathbf{5 6 8 . 6 2 7}$ & $\mathbf{6 3 4 . 4 4 2}$ & $\mathbf{6 9 6 . 9 0 5}$ & $\mathbf{7 8 1 . 0 1 3}$ & $\mathbf{9 1 1 . 5 0 4}$ \\
\hline
\end{tabular}

Sumber: BPS, Hasil Sensus Penduduk 1961,1971,1980,1990,2000 dan 2010²

Luas wilayah Kecamatan Banguntapan adalah 2.865,9537 Ha. Wilayah administrasi kecamatan Banguntapan meliputi 8 Desa:1. Desa Banguntapan; 2. Desa Baturetno; 3. Desa Singosaren; 4. Desa Jagalan; 5. Desa Tamanan; 6. Desa Wirokerten; 7. Desa Potorono; 8. Desa Jambidan.

Sesuai dengan data yang ada di dalam data Pemerintah, Kecamatan Banguntapan dihuni oleh 17.147 KK. Jumlah keseluruhan penduduk asli Kecamatan Banguntapan adalah 76.513 Orang dengan jumlah penduduk laki-laki 37.752 orang dan penduduk perempuan 38.761 orang. Tingkat kepadatan penduduk di Kecamatan Banguntapan adalah 2670 jiwa/km2. Sebagian besar penduduk Kecamatan Banguntapan adalah petani. Dari data monografi Kecamatan tercatat 17.869 orang atau 23,39\% penduduk Kecamatan Banguntapan bekerja di sektor pertanian. ${ }^{3}$ Berkaitan dengan hal tersebut, penulis memilih obyek penelitian di 3 (tiga) Desa, yaitu Desa Banguntapan, Desa Baturetno, dan Desa

\footnotetext{
2 Diterbitkan oleh Badan Pusat Statistik Daerah Istimewa Yogyakarta, April, 2013.

${ }^{3}$ http://kec-banguntapan.bantulkab.go.id/hal/profil, Kecamatan Banguntapan, Akses 16 Maret 2016.
} 
Wirokerten. Dari 8 desa tersebut ketiga Desa itulah yang paling relevan untuk diadakan penelitian, dikarenakan jumlah penduduknya terbesar, yang kemudian dalam penelitian ini disebut sebagai Kecamatan Banguntapan. Dari hasil prapenelitian penulis, di daerah obyek tersebut telah ditemukan penyalahgunaan fungsi Tanah Kas Desa yang tidak sesuai dengan peruntukannya. Banyak Tanah Kas Desa di beberapa lokasi yang telah beralih fungsi menjadi tempat tinggal atau pemukiman bahkan telah menjadi perkampungan. Hal ini bertentangan dengan Pasal 14 Peraturan Gubernur DIY Nomor. 65 Tahun 2013 Tentang Tanah Kas Desa.

Masalah ini telah terjadi selama bertahun-tahun dimulai ketika puluhan tahun yang lalu berawal dari beberapa warga yang tidak punya tempat tinggal memohon kepada pemerintah desa melalui kepala desa untuk menumpang Tanah Kas Desa sementara sampai mendapatkan tempat tinggal, kemudian di izinkan oleh Pemerintah Desa menggunakan Tanah Kas Desa tersebut dengan syarat tidak didirikan bangunan permanen di atas tanah tersebut dan sewaktu-waktu bisa ambil kembali jika diperlukan oleh desa dan seiring berjalanya waktu semakin banyak masyarakat yang menetap di tanah tersebut dan mendirikan bangunan permanen. ${ }^{4}$

Hingga sampai saat ini belum ada upaya dari pemerintah Desa setempat untuk mengembalikan fungsi lahan tersebut. Adapun yang telah terjadi selama ini adalah masyarakat desa hanya membayar uang sewa atau pungutan dengan perjajian tertulis maupun tidak tertulis kepada Pemerintah Desa setempat setiap tahunnya sesuai dengan nilai tanah yang diduduki. Bahkan ada pula terjadi jual beli rumah bangunan yang berdiri di atas tanah kas desa yang di tuangkan dalam akta notaris. Hal tersebut tidak sesuai dengan Pergub Nomor 65 Tahun 2013 Tentang Tanah Kas Desa Pasal 12 ayat (2) yang melarang mengalihkan penguasaan atau menyewakan Tanah Kas Desa kepada pihak lain.

Asas pemisahan horizontal di dalam pemberlakuan hukum pertanahan Indonesia memberikan pemisahan antara kepemilikan tanah dengan apa yang melekat didalamnya, hanya yang berhubungan langsung dengan penggunaan tanah saja yang dapat dimanfaatkan. Hal ini membatasi kewenangan pemilik atas tanah dalam memanfaatkan tanah, karena pemanfaatan apa yang terkandung di dalam tanah dan yang melekat diatasnya harus dapat dibuktikan bahwa memang hanya yang berkaitan dengan penggunan tanah tersebut.

Wawancara dengan Wardjono, Kepala Bagian Pemerintahan, Desa Banguntapan di Yogyakarta, 14 
Oleh karena itu perlu kiranya adanya solusi untuk mengatasi problematika tersebut supaya Tanah Kas Desa dapat di optimalkan kembali sebagaimana peruntukanya dan juga penegakan aturan sesuai dengan Peraturan Perundang-Undangan yang berlaku. Proses pengadaan tanah pengganti Tanah Kas Desa kiranya perlu dilakukan untuk mengatasi persoalan ini. Sehingga memperoleh kejelasan hukum tentang tanah yang diduduki masyarakat di atas Tanah Kas Desa tersebut.

Dalam Romawi IV, huruf A Nomor 3 point (c) Instruksi Menteri Dalam Negeri Nomor 22 Tahun 1996 desebutkan bahwa "Tanah Kas Desa tidak dapat dipindah tangankan kepada pihak lain kecuali diperlukan dengan keputusan Desa dan disahkan oleh Bupati/Walikota setelah mendapat ijin tertulis dari Gubernur". Berdasarkan landasan itu banyak daerah yang memiliki Tanah Kas Desa yang melakukan pemindah tanganan tanahtanah Kas Desa kepada pihak ketiga. Pemindah tanganan tanah-tanah Kas Desa kepada pihak ketiga tersebut umumnya ditempuh dengan cara 'tukar guling', yaitu pelepasan Tanah Kas Desa yang harus diganti dengan tanah juga senilai dengan tanah yang telah dilepaskan atas nama Pemerintah Desa.

Pelepasan Tanah Kas Desa yang dimaksud yaitu berkaitan dengan kepentingan umum sesuai dengan Kebijaksanaan Umum Keputusan Gubernur Daerah Istimewa Yogyakarta Nomor 82 Tahun 2003 tentang Pedoman Pelepasan, Perubahan Peruntukan, Sewa-menyewa tanah kas desa di Propinsi Daerah Istimewa Yogyakarta yaitu dengan cara: Pengajuan permohonan tertulis kepada Lurah Desa dengan menyertakan proposal rencana penggunaan Tanah Kas Desa, Setelah Kepala Desa dan BPD membahas permohonan tersebut diajukan permohonan rekomendasi kepada Bupati. Berdasarkan peraturan perundang-undangan yang berlaku Bupati dapat menerima atau menolak permohonan rekomendasi. Jika dalam hal permohonan diterima, Bupati menyampaikan permohonan disertai rekomendasi dari Gubernur. Dalam hal permohonan diterima, maka Gubernur menerbitkan Keputusan Gubernur.

Kemudian sesuai dengan Peraturan Menteri Negara Agraria Nomor 3 Tahun 1997 tentang Pendaftaran Tanah Pasal 131 ayat (3) dalam proses pelaksanaan pengadaan tanah Pengganti Tanah Kas Desa yang dilepaskan harus dilakukan dengan cara, pemohon dapat menghadap Notaris untuk mengurus Akta Pelepasan Hak atas obyek tanah sebagai pengganti yang senilai dengan Tanah Kas Desa yang dilepaskan. Dalam klausul akta pelepasan hak atas tanah tersebut di sebutkan bahwa Pihak Pertama melepaskan hak kepada negara untuk diterima oleh Pihak Kedua selaku Pemerintah Desa yang di wakilkan oleh 
Kepala Desa Sebagai penerima. Kemudian Akta Pelepasan Hak tersebut dilekatkan dalam Berita Acara Pernyataan Pelepasan Hak yang ditandatangani pemegang hak dengan disaksikan Panitia Pelaksana Pengadaan Tanah Kabupaten dan Panitia Pengawas Propinsi.

Dari latar belakang tersebut diatas penting kiranya untuk dilakukan penelitian. Hasil penelitian ini diharapkan dapat dijadikan bahan masukan untuk perbaikan sistem pengelolaan Tanah Kas Desa sesuai dengan prosedur yang berlaku pada masa yang akan datang.

\section{Rumusan Masalah}

Berdasarkan uraian di atas, permasalahan dalam penelitian ini, pertama: bagaimana bentuk penyalahgunaan kepemilikan hak atas Tanah Kas Desa yang di duduki warga sebagai tempat tinggal? Kedua, bagaimana upaya Pemerintah Desa dalam mengatasi penyalahgunaan fungsi Tanah Kas Desa di Kecamatan Banguntapan? Ketiga, bagaimana Penegakan Hukum proses pengurusan, berkaitan dengan penyalahgunaan fungsi Tanah Kas Desa Di Kecamatan Banguntapan Kabupaten Bantul Daerah Istimewa Yogyakarta?

\section{Tujuan Penelitian}

Adapun tujuan penelitian ini adalah, pertama, untuk mengetahui bentuk penyalahgunaan kepemilikan hak atas Tanah Kas Desa yang di duduki warga sebagai tempat tinggal. Kedua, untuk mengetahui upaya Pemerintah Desa dalam mengatasi penyalahgunaan fungsi Tanah Kas Desa di Kecamatan Banguntapan Kabupaten Bantul Daerah Istimewa Yogyakarta. Ketiga, mengetahui bentuk penegakan hukum proses pengurusan, berkaitan dengan penyalahgunaan fungsi Tanah Kas Desa di Kecamatan Banguntapan Kabupaten Bantul Daerah Istimewa Yogyakarta.

\section{Metode Penelitian}

Penelitian ini menggunakan metode yuridis empiris yaitu suatu penelitian yang meneliti data sekunder terlebih dahulu dan kemudian dilanjutkan dengan penelitian data primer di lapangan. ${ }^{5}$ Pendekatan yang digunakan adalah pendekatan peraturan perundangundangan. Subjek penelitian yang dijadikan sebagai rujukan dalam penelitian ini adalah pihak-pihak yang dipilih peneliti untuk memperoleh informasi dan keterangan terhadap masalah yang akan diteliti antara lain adalah: a. Bupati Kabupaten Bantul (Kepala Daerah

${ }^{5}$ Soerjono Soekanto, Pengantar Penelitian Hukum, cetakan pertama, Universitas Indonesia Press, Jakarta, 1984, hlm. 7. 
Tingkat II), b. Kepala Kantor Pertanahan Bantul, c. Kepala Kecamatan Banguntapan, d. Kepala Desa se-Kecamatan Banguntapan, e. Notaris. Data yang diperoleh dari hasil penelitian akan dianalisis secara deskriptif kualitatif.

\section{Hasil Penelitian dan Pembahasan}

Menurut Peraturan Daerah Propinsi Daerah Istimewa Yogyakarta Nomor 5 Tahun 1985 dalam Pasal 9, tanah-tanah Desa yang berupa tanah kas desa, bengkok/lungguh, pengarem-arem, kuburan dan lain-lain yang sejenisnya yang dikuasai oleh dan merupakan kekayaan desa dilarang untuk dilimpahkan kepada pihak lain, kecuali diperlukan untuk kepentingan proyek-proyek yang ditetapkan denga Keputusan Desa.

Dalam ketentuan Peraturan Gubernur Daerah Istimewa Yogyakarta Nomor 06 Tahun 2013 tentang Tanah Kas Desa Pasal 14 disebutkan: "Sewa Tanah Kas Desa sebagaimana dimaksud dalam Pasal 11 ayat (1) yaitu tentang pengoptimalan pendapatan asli desa, dilarang untuk dipergunakan sebagai pemukiman atau tempat tinggal."

Berkaitan dengan Pengelolaan juga diatur pada Peraturan Menteri Dalam Negeri Nomor 04 Tahun 2007 Tentang Pedoman Pengelolaan Kekayaan Desa, dalam Pasal 15 diterangkan sebagai berikut: 1 . Kekayaan Desa yang berupa tanah Desa tidak diperbolehkan dilakukan pelepasan hak kepemilikan kepada pihak lain, kecuali diperlukan untuk kepentingan umum; 2. Pelepasan hak kepemilikan tanah desa sebagaimana dimaksud pada ayat (1) dilakukan setelah mendapat ganti rugi sesual harga yang menguntungkan desa dengan memperhatikan harga pasar dan Nilai Jual Objek Pajak (NJOP); 3. Penggantian ganti rugi berupa uang harus digunakan untuk membeli tanah lain yang lebih baik dan berlokasi di Desa setempat; 4. Pelepasan hak kepemilikar. timah desa sebagaimjlrta dimaksud pada ayat (1) ditetapkan dengan Keputusan Kepala Desa; 5. Keputusan Kepala Desa sebagaimana dimaksud pada ayat (3) diterbitkan setelah mendapat persetujuan BPD dan mendapat ijin tertulis dari Bupati/Walikota dan Gubernur.

Lawrence M. Friedman mengemukakan bahwa efektif dan berhasil tidaknya penegakan hukum tergantung unsur-unsur sistem hukum, yakni: pertama, struktur Hukum, yaitu keseluruhan institusi-institusi hukum yang ada beserta aparatnya, mencakupi antara lain kepolisian dengan para polisinya, kejaksaan dengan jaksanya, pengadilan dengan hakimnya, dan lain-lain. Kedua, substansi Hukum, yaitu keseluruhan aturan hukum, norma hukum dan asas hukum, baik yang tertulis maupun tidak tertulis, termasuk putusan pengadilan. Ketiga, kultur Hukum, yaitu opini-opini, kepercayaan-kepercayaan (keyakinan- 
keyakinan), kebiasaan-kebiasaan, cara berpikir, dan cara bertindak, baik dari para penegak hukum maupun dari warga masyarakat, tentang hukum dan berbagai fenomena yang berkaitan dengan hukum. polisinya, kejaksaan dengan jaksanya, pengadilan dengan hakimnya, dan lain-lain.

Struktur hukum menyangkut aparat penegak hukum, substansi hukum meliputi perangkat perundang-undangan dan budaya hukum merupakan hukum yang hidup (living law) yang dianut dalam suatu masyarakat. Dalam kerangka berpikir seperti ini, hak-hak perorangan atas tanah tidak bersifat mutlak, tetapi selalu ada batasnya, yakni kepentingan orang lain, masyarakat atau negara. Dengan demikian dituntut penguasaan dan penggunaan tanah secara wajar dan bertanggung jawab, disamping bahwa setiap hak atas tanah yang dipunyai diletakkan pula kewajiban tertentu. Ada pertanggungjawaban individu terhadap masyarakat melalui terpenuhinya kepentingan bersama/kepentingan umum.

Penegakan hukum berkaitan dengan penyalahgunaan fungsi Tanah Kas Desa tidak terlepas dari Pemerintah itu sendiri. Dalam hal ini pemerintah desa harus membuat kebijakan terkait kesalahan yang telah dilakukan oleh Pemerintah Desa sebelumnya, dalam hal masyarakat mendirikan bangunan permanen diatas tanah kas desa tidak semestinya akan terus dilaksanakan dengan pembayaran uang sewa kepada pemerintah desa. Selain hal tersebut menyalahi peraturan Perundang-Undangan, juga masyarakat tidak mendapatkan kepastian hukum atas tanah yang ditempatinya.

Dalam hal ini Badan Pertanahan Nasional tidak berhubungan langsung dengan penyalahgunaan fungsi tanah kas desa yang menjadi pemukiman. Pemerintah Desalah yang mempunyai data tentang masyarakat yang menggunakan lahan tanah kas desa sebagai pemikiman, tugas Badan Pertanahan Nasional hanya mendata seluruh Tanah yang ada diwilayahnya. Untuk mengatasi hal tersebut perlu dibentuk tim untuk menyelesaikan persoalan kepastian hukum atas tanah tersebut. Pemerintah Desa harus aktif serta menggandeng Pemerintah Daerah untuk mengatasinya. Menurut Sudikno Mertokusumo, dalam bukunya yang berjudul Mengenal Hukum Suatu Pengantar, kepastian hukum adalah jaminan bahwa hukum dijalankan, bahwa yang berhak menurut hukum dapat memperoleh haknya dan bahwa putusan dapat dilaksanakan. Walaupun kepastian hukum erat kaitannya dengan keadilan, namun hukum tidak identik dengan keadilan. Hukum bersifat umum, mengikat setiap orang, bersifat menyamaratakan, sedangkan keadilan bersifat subyektif, individualistis, dan tidak menyamaratakan. Bahwa Desa Banguntapan merupakan desa dengan jumlah penyalahgunaan fungsi tanah kas desa yang dijadikan pemukiman terbanyak di Kecamatan Banguntapan, dikarenakan letak geografis desa ini adalah yang paling 
strategis diantara desa yang lain, sehingga banyaknya penduduk luar daerah banguntapan yang berdatangan ke desa ini. Nama yang tercatat dalam buku daftar penghuni tanah kas desa tidak semua adalah orang yang menghuni saat ini karena ada yang sudah turun ke anaknya ataupun adanya peralihan hak terhadap bangunan ke pihak lain. Adapun bentuk pelanggaranya sebagai berikut: 1 . Kecerobohan Pemerintah Desa sebelumnya dan warga penyewa adalah sebab banyaknya penyalahgunaan fungsi tanah kas desa; 2 . Didirikannya bangunan permanen seharusnya tidak dibenarkan; 3. Peralihan hak sewa tanah kas desa berikutnya jika tidak seijin dari pemerintahan desa dalam hal dibuat dihadapan notaris, maka notaris yang bersangkutan turut berperan salah.

Pemerintah Desa yang sekarang ini terhadap tanah kas desa yang sudah beralih fungsi menjadi pemukiman hanyalah sekedar pendataan dan meminimalisir terjadinya pelanggaran atau penyalahgunaan fungsi tanah ka desa dititik lain. Dalam hal ini yang selama ini di lakukan adalah pungutan pertahun untuk penghuni tanah kas desa kepada pemerintah desa.

Kepala desa yang berikutnya seharusnya meminimalisir pelanggaran dan tidak permisif yaitu serba membolehkan dan mengizinkan semua kehendak warganya, akan tetapi harus dengan peruntukan sesuai dengan peraturan perundang-undangan yang berlaku. Ketat dalam mengontrol mengawasi dalam hal-hal penguasaan tanah kas desa. Ketat dalam mengasai, evaluasi dalam pengawasan peralihan tanah kas desa. Dan memberikan sanksi yang tegas terhadap segala bentuk pelanggaran yang terjadi.

Di Desa Baturetno dan Desa Wirokerten dalam mengantisipasi terjadinya penyalahgunaan fungsi tanah kas desa, terhadap masyarakat yang memanfaatkan lahan tanah kas desa dibawah 2 tahun yang tidak memerlukan ijin bupati dan gubernur. Dilakukan dengan perjanjian sewa menyewa dan surat pernyataan untuk tidak mendirikan bangunan permanen dan sewaktu-waktu pemerintah desa dapat mengambil alih kembali tanah kas desa.

Perlu adanya tindakan tegas oleh Pemerintah Desa, Kecamatan dan Kabupaten mengenai kepastian hukum terhadap hak tanah kas desa yang telah terlanjur didirikan bangunan permanen dan perlindungan hukum terhadap masyarakat yang telah mendirikan bangunan permanen. Dalam hal ini tidak sepenuhnya masyarakat dapat disalahkan atas hal tersebut karena pemerintah desa terdahulu juga berperan dalam pelanggaran perbuatan hukum ini. 
Pensertifikatan tanah kas desa dengan model tukar guling kiranya perlu dilakukan, yaitu penggantian tanah dengan tanah lain yang mempunyai nilai yang setara dengan dicarikan tanah pengganti terhadap tanah kas desa yang telah didirikan bangunan permanen dengan tanah yang terletak di tempat lain dan diatas namakan pemerintah desa di dalam desa jika tidak memungkinan bisa di luar desa dalam satu wilayah kecamatan.

Dalam hal ini perlu melibatkan pemerintahan desa, pemerintah kecamatan, pemerintah daerah, Notaris-PPAT dan Badan Pertanahan Nasional kaitanya dengan prosedur penggantian tanah kas desa oleh masyarakat. Prosedur penggantian harga tanah oleh masyarakat yaitu: 1. Pengumpulan warga dan memberikan penjelasan serta sosialisasi kepada masyarakat untuk penegakan ketertiban administrasi desa; 2. Masyarakat membayar harga tanah sesuai dengan nilai tanah yang ditempati yang ditentukan pemerintah; 3. Penunjukan bank rekanan notaris atau koperasi yang disepakati oleh pemerintah desa; 4. Pembayaran dilakukan dengan jangka waktu sesuai kesanggupan masyarakat dan paling lama 15 tahun; 5. Setelah tercapainya pembayaran sesuai harga yang telah ditetapkan, maka di lakukan pelepasan hak tanah kas desa oleh pemerintah desa, notaris dan BPN serta penggantian tanah kas desa dengan pensertifikatan atas nama desa; 6. Pensertifikatan terhadap bekas tanah kas desa ke atas nama masyarakat yang telah mendirikan banguna permanen diatasnya.

Memang tidak mudah dan banyak kendala dalam pelaksanaan penegakan hukum, akan tetapi dengan keterlibatan masyakarat dan pemerintah dalam proses penegakan hukum ini sekiranya penulis berkeyakinan dapat terlaksana dengan baik. Oleh karena itu dukungan dan partisipasi semua institusi pemerintah sangat penting.

\section{Penutup}

Berdasarkan pembahasan sebelumnya, maka dapat ditarik kesimpulan, bahwa proses penyalahgunaan tanah kas desa di Kecamatan Banguntapan Kabupaten Bantul melibatkan berbagai pihak mulai dari pemerintah desa, masyarakat, dan juga notaris setempat. Tanah Kas Desa merupakan salah satu aset desa yang berharga karena berfungsi sebagai sumber pemasukan terbesar desa maka sebaikanya keberadaanya harus dijaga. Pemerintah desa harus bertindak tegas terhadap kelangsungan tanah kas desa dan memberikan sanksi terhadap pelanggaraan yang terjadi. Sehingga kekayaan desa tersebut bisa dirasakan manfaatnya oleh semua orang terutama warga desa dengan tidak melanggar peraturan yang berlaku. 


\section{Daftar Pustaka}

\section{Buku}

Ashsofa, Burhan, Metode Penelitian Hukum, Jakarta: Rieneka Cipta, 1996.

Departemen Pekerjaan Umum Sekretariat Jenderal, Biro Hukum. Buku Pedoman: Tata cara Pembebasan tanah Untuk Kepentingan Pemerintah, Jakarta: Badan Penerbit Pekerjaan Umum.

Hanitijo Soematro, Ronny, Metode penelitian Hukum, Jakarta: Ghalia Indonesia, 1983.

Harsono, Budi. Hukum Agraria Indonesia, Sejarah Pembentukan Undang-Undang Pokok Agraria. Isi dan Pelaksanaanya, Jakarta: Djambatan, 1997.

Mertokusumo, Sudikno, Mengenal Hukum Suatu Pengantar, Yogyakarta: Liberty, 2003.

Sembiring, Julius. Tanah Negara, Yogyakarta: STPN Press, 2012.

Soekanto, Soerjono, Pengantar Penelitian Hukum, Jakarta: Universitas Indoesia Press, 1984

\section{Peraturan Per Undang-Undangan}

Undang-Undang Dasar 1945.

Indonesia. Undang Undang Nomor 06 Tahun 2014 tentang Desa.

Indonesia. Peraturan Menteri Dalam Negeri Nomor 04 Tahun 2007 Tentang Pedoman Pengelolaan Kekayaan Desa.

Indonesia. Dalam Instruksi Menteri Dalam Negeri Nomor 22 Tahun 1996 Tentang Pengadaan, Pengelolaan dan Pengembangan Tanah Kas Desa.

Indonesia. Peraturan Daerah Propinsi Daerah Istimewa Yogyakarta Nomor 5 Tahun 1985.

Indonesia. Peraturan Gubernur Daerah Istimewa Yogyakarta Nomor 65 Tahun 2013 Tentang Tanah Kas Desa.

Indonesia. Keputusan Gubernur Daerah Istimewa Yogyakarta Nomor 82 Tahun 2003 tentang Pedoman Pelepasan, Perubahan Peruntukan, Sewa-menyewa tanah kas desa di Propinsi Daerah Istimewa Yogyakarta.

\section{Data Elektronik}

https://id.wikipedia.org/wiki/Desa, Desa, Akses 14 Maret 2016

http://kec-banguntapan.bantulkab.go.id/hal/profil, Kecamatan Banguntapan, Akses 16 Maret 2016. 